U.S. DEPARTMENT OF THE INTERIOR

U.S. GEOLOGICAL SURVEY

\title{
Distribution of Mineral Deposits in the United States - Mexico Border Region
}

\author{
by \\ Center for Inter-American Mineral Resource Investigations \\ (CIMRI)
}

\author{
with contributions by \\ Greta J. Orris \\ Karen S. Bolm \\ Marguerite Carbonaro \\ Floyd Gray \\ Keith R. Long \\ Norman J Page \\ John-Mark Staude \\ Tina Wells
}

Open-File Report

93-532

This report is preliminary and has not been reviewed for conformity with U.S. Geological Survey editorial standards or with the North American Stratigraphic Code. Any use of trade, product or firm names is for descriptive purposes only and does not imply endorsement by the U.S. Government. 


\title{
TABLE OF CONTENTS
}

\author{
Introduction 1 \\ Study Area and Background 1 \\ Discussion of Mineralization 1 \\ Data 4 \\ United States 6 \\ Arizona 6 \\ California (southern) 6 \\ New Mexico 6 \\ Texas 6 \\ Mexico 6 \\ Baja California Norte/Sonora 7 \\ Chihuahua 7 \\ Coahuila 7 \\ Nuevo Leon/Tamaulipas 7 \\ Metallic Minerals 7 \\ Industrial Minerals 13 \\ References 13
}

\section{FIGURES}

Figure 1. The CIMRI borderlands study area and the number of sites of metallic (M), industrial (I), and metallic and industrial (B) minerals in MRDS as of May 1993.

Figure 2. Distribution of all mines and occurrences in and near the CIMRI borderlands study area as recorded in MRDS in May 1993.

Figure 3. Spatial distribution of major Ag mines and occurrences in and near the CIMRI borderlands study area as recorded in MRDS, May 1993.

Figure 4. Spatial distribution of major Au mines and occurrences in and near the CIMRI borderlands study area as recorded in MRDS, May 1993.

Figure 5. Spatial distribution of major $\mathrm{Cu}$ mines and occurrences in and near the CIMRI borderlands study area as recorded in MRDS, May 1993.

Figure 6. Spatial distribution of major $\mathrm{Pb}-\mathrm{Zn}$ mines and occurrences in and near the CIMRI borderlands study area as recorded in MRDS, May 1993.

Figure 7. Spatial distribution of major Sn mines and occurrences in and near the CIMRI borderlands study area as recorded in MRDS, May 1993. 
Figure 8. Spatial distribution of B mines and occurrences in and near the CIMRI borderlands study area as recorded in MRDS, May 1993.

Figure 9. Spatial distribution of barite, celestite, and fluorite mines and occurrences in and near the CIMRI borderlands study area as recorded in MRDS, May 1993.

Figure 10. Spatial distribution of clay mines and occurrences in and near the CIMRI borderlands study area as recorded in MRDS, May 1993.

Figure 11. Spatial distribution of diatomite mines and occurrences in and near the CIMRI borderlands study area as recorded in MRDS, May 1993.

Figure 12. Spatial distribution of feldspar mines and occurrences in and near the CIMRI borderlands study area as recorded in MRDS, May 1993.

Figure 13. Spatial distribution of graphite mines and occurrences in and near the CIMRI borderlands study area as recorded in MRDS, May 1993.

Figure 14. Spatial distribution of gypsum mines and occurrences in and near the CIMRI borderlands study area as recorded in MRDS, May 1993.

Figure 15. Spatial distribution of halite mines and occurrences in and near the CIMRI borderlands study area as recorded in MRDS, May 1993.

Figure 16. Spatial distribution of limestone mines and occurrences in and near the CIMRI borderlands study area as recorded in MRDS, May 1993.

Figure 17. Spatial distribution of perlite mines and occurrences in and near the CIMRI borderlands study area as recorded in MRDS, May 1993.

Figure 18. Spatial distribution of phosphate mines and occurrences in and near the CIMRI borderlands study area as recorded in MRDS, May 1993.

Figure 19. Spatial distribution of rare earth element mines and occurrences in and near the CIMRI borderlands study area as recorded in MRDS, May 1993. 
Figure 20. Spatial distribution of sand and gravel mines and occurrences in and near the CIMRI borderlands study area as recorded in MRDS, May 1993.

Figure 21. Spatial distribution of crushed stone and dimension stone quarries and occurrences in and near the CIMRI borderlands study area as recorded in MRDS, May 1993.

Figure 22. Spatial distribution of sulfur mines and occurrences in and near the CIMRI borderlands study area as recorded in MRDS, May 1993.

Figure 23. Spatial distribution of zeolite mines and occurrences in and near the CIMRI borderlands study area as recorded in MRDS, May 1993. 


\section{INTRODUCTION}

This report documents the distribution of selected metallic and industrial mineral deposits along the United States - Mexico border and is part of one of the first cross-border studies of mineral resources. These data are stored in the U.S. Geological Survey's Mineral Resources Data System (MRDS) and represent the data set as of May 1993. The staff of the Center for Inter-American Mineral Resource Investigations (CIMRI) has significantly augmented the preexisting MRDS data sets for the study area by addition of industrial mineral and metallic mines and occurrences not previously in MRDS and by upgrading and updating of information for sites previously in MRDS. Certain parts of the data set are incomplete, such as sand and gravel deposits in Arizona, and work will continue in CIMRI to improve the mineral site information for the border states of the United States and Mexico. This report briefly describes CIMRI's borderlands studies, gives a preliminary analysis of some of the data, and presents the spatial distribution of the mineral site data. The MRDS mineral site data are available from the Mirerals Information Office, 340 N. 6th Avenue, Tucson, Arizona, 85705-8325.

\section{STUDY AREA AND BACKGROUND}

CIMRI collects data on the mines and mineral occurrences of the border region as part of an integrated study of the mineral economy of the borderlands region. The study area includes parts of the border States of Mexico and the United States as shown in figure 1. Much of the area is relatively undeveloped and mining is a key industry. U.S. Mexico mineral trade, already substantial, is likely to expand in the near future, especially under expected free trade agreements. The study area extends relatively equal distances on both sides of the border, includes the first and (or) second largest cities in each state, and encompasses more than one million square kilometers. As delineated, the border region is one of the world's largest producers of celestite ( $\mathrm{Sr}$ ), fluorite, gypsum, and copper. Other significant products include barite, dimension stone, gold, potash, pumice, silver, sulfur and sulfuric acid, and zeolites. At least thirty other metallic and nonmetallic mineral products have been produced in the study area. Although energy minerals are outside the scope of this report, the borderlands region is a major producer of these minerals.

\section{DISCUSSION OF MINERALIZATION}

Relative to the geologic framework of the study area, analysis of the data set of over 1000 metallic sites in the border region of Mexico and 5000 in the border region of the United States shows certain apparent 


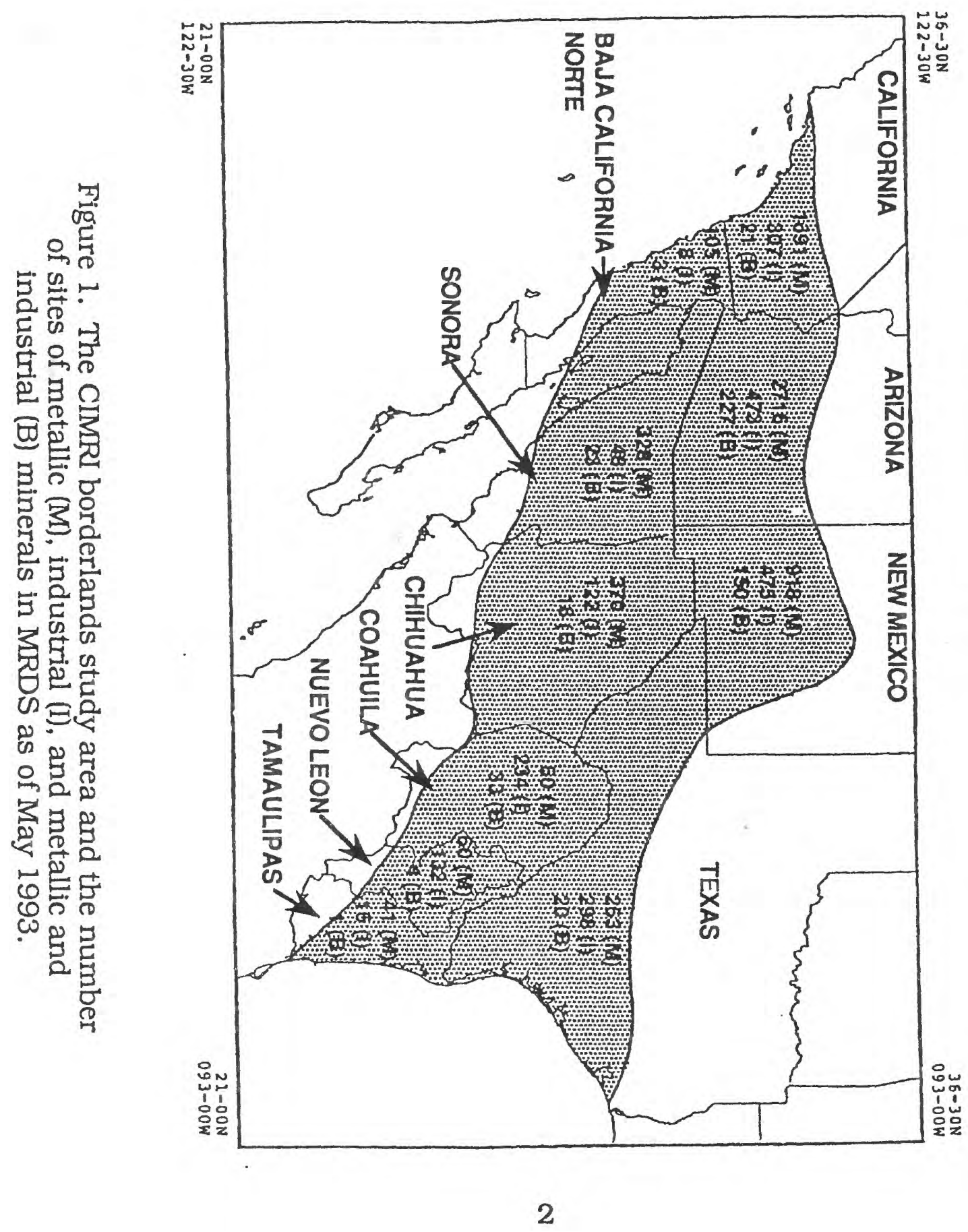


trends and relations. Proterozoic crystalline rocks host a wide variety of deposit types. A major geochronological boundary between older Precambrian rocks (1.7-1.8 b.y.) and younger Precambrian rocks (1.61.7 b.y.) trends northeast-southwest across the scattered Precambrian outcrops of Arizona and New Mexico. The older rocks host major mineralization, while the younger rocks are relatively poor in mineral deposits. In central Arizona, the older group of Precambrian rocks host major massive sulfide deposits. Other deposits of Precambrian age include a variety of pegmatite minerals including spodumene, mica, and feldspar, and chrysotile asbestos. In addition, Precambrian rocks host gold deposits along detachment faults and tungsten vein deposits, but for these deposit types, but mineralization occurred much later during the Mesozoic or Tertiary.

The Paleozoic and Mesozoic eras are largely represented by platform rocks consisting primarily of limestone, dolomite, shale, sandstone, and chert in the study area. Much of the mining in the Paleozoic rocks is for industrial minerals such as ornamental stone, limestone for cement and lime, and barite. The Mesozoic rocks host celestite, fluorite, phosphate, and a wide variety of other mineral deposits. Other mineral deposits hosted in these rocks include $\mathrm{Pb}-\mathrm{Zn}$ replacement and vein deposits, as well as manganese and copper deposits. Much of the metallic and fluorite mineralization in these rocks is of late Mesozoic and Tertiary age.

One of the more interesting trends occurs in the western part of the study area where five separate tectonomagmatic events occurred over the past 150 million years producing five superimposed metallogenic belts. Large portions of the present border region may have been transported into their present locations by large scale plate tectonics subsequent to 150 m.y. (Silver and Anderson, 1978).

The five tectonomagmatic events were five distinct pulses that can be categorized by age into Late Jurassic, Cretaceous, Late CretaceousEarly Tertiary, Middle Tertiary, and Late Tertiary-Recent. In the Late Jurassic, shearing and mafic magmatism gave rise to minor metallic ore deposits. During the Cretaceous, Au-Ag veins, $\mathrm{Cu}-\mathrm{W}$ skarns, and numerous pegmatites formed in the batholithic regions of the western border region. These deposits have yielded significant amounts of $\mathrm{W}$ and other metals.

The Late Cretaceous-Early Tertiary ("Laramide") was a time of extensive volcanic and plutonic activity. World class $\mathrm{Cu}-(\mathrm{Mo}), \mathrm{Ag}-\mathrm{Au}$, and $\mathrm{Pb}-\mathrm{Zn}-\mathrm{Ag}$ deposits formed in and around the magmatic arc. From 80-40 m.y., the center of magmatism progressed from west to east, superimposing the effects of multiple periods of magmatism and mineralization on the rocks of the area. This is one of the fundamental reasons why the border region is so well mineralized. This progression eventually formed a number of relatively large gold and silver districts.

The Middle Tertiary (Late Oligocene-Early Miocene) is characterized by deposits of $\mathrm{Au}-\mathrm{Ag}, \mathrm{Pb}-\mathrm{Zn}-\mathrm{Ag}$, fluorite, Se, celestite, potash, gypsum, halite, and other evaporites. The environments of 
mineralization ranged from continental volcano-magmatic to fault block basins. The Late Tertiary to recent time is characterized by hot spririg gold, red bed copper, volcanic sulfur, borate, and evaporite deposits.

Detailed analysis of the relationship between the mineral occurrence data and other geologic information should help determine additional correlations. As an example, the Cretaceous batholith of California is more mafic and isotopically primitive than the Laramide batholith in Arizona and New Mexico which is intermediate in composition and also intermediate between crustal and mantle in terms of epsilon $\mathrm{Nd}, \mathrm{Rb} / \mathrm{Sr}$, and alkalinity, The middle Tertiary plutons of Arizona to Texas are crustally derived and host mineral deposits characteristically associated with crustal and low temperature magmatism. From our compilation we can document similar trends in northern Mexico and recognize other trends that extend across the border.

\section{DATA}

Through May 1993, the CIMRI borderlands project upgraded over 2000 records and added over 1500 new records to MRDS. The distribution of all MRDS-recorded deposits in the borderlands study area is shown in figure 2 . The data were entered into MRDS by Karen Bolm of the Tucson Minerals Information Office and by Marguerite Carbonaro and Tina Wells of CIMRI. The records reflect the varying quality of the source data and rely on previously published information, but may include data from on-site mapping and sampling and information from unpublished compilations, notes, and files. The newer data are commonly more accurately located than earlier records and many locations are precise to within 10 seconds or less; data in the U.S. are commonly more precisely located than data in Mexico. Because different commodities have received varying degrees of previous study and because a wide variety of minerals are being looked at during this study, the data are obviously not of even quantity or quality across all commodities. Detailed modeling or analysis of maps included here must take into account the varying quality and completeness of data as well as the superimposed mineralization, host rock types, and types of mineralization. With this in mind, the data can be used to better understand, define and evaluate mineral resources in the border region.

Continued data collection and more detailed analysis will provide further insights into the mineral economics, market structures, geologic relations, and mineral processing specifics. The value of these data is that a more uniform, newly integrated data set is provided that can be used by a broad range of clients to solve both academic and applied problems. 


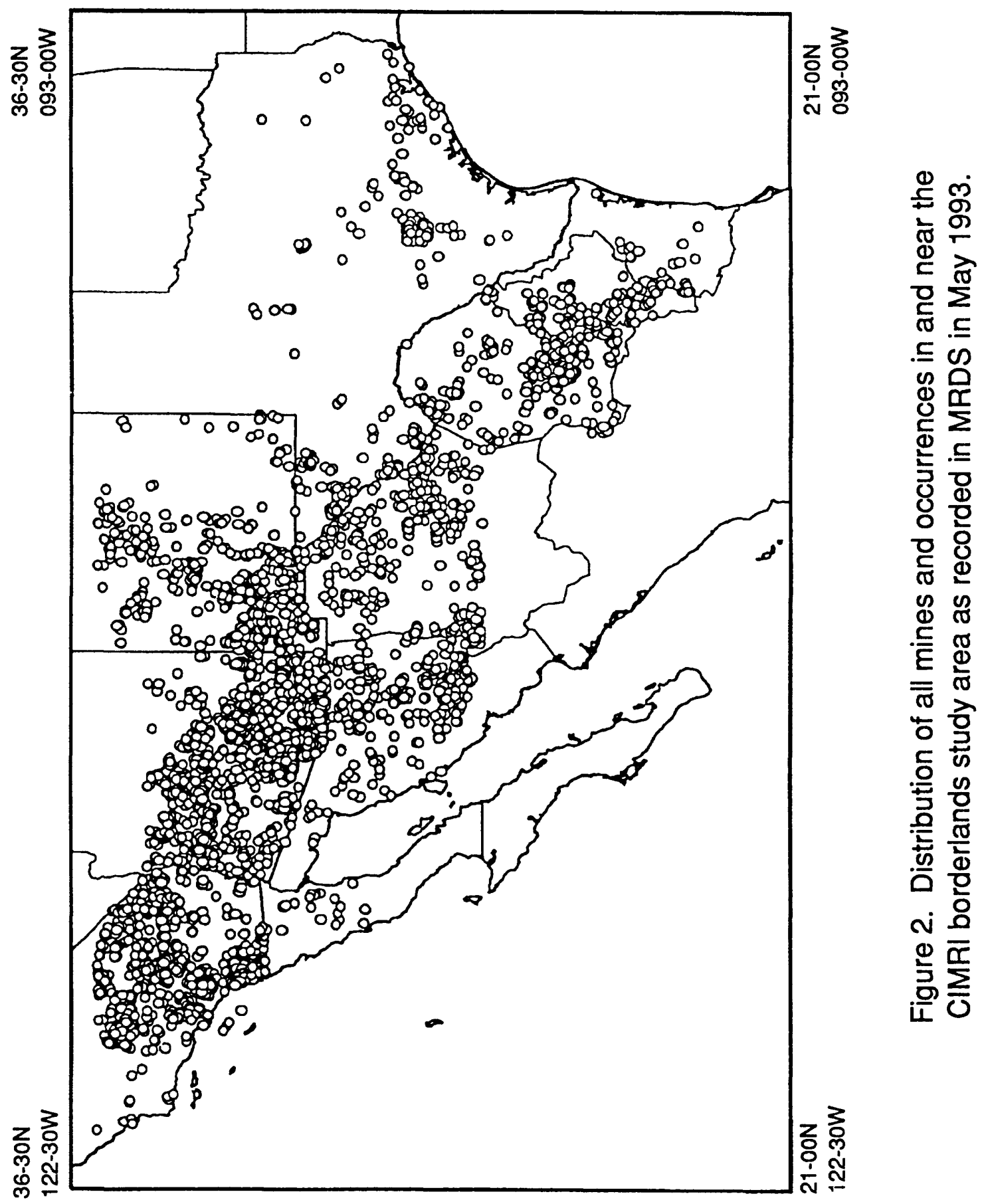




\section{United States}

Responsibility for upgrading and completing the mineral data set for the United States portion of the study was distributed by state amongst CIMRI staff as follows:

$$
\begin{aligned}
& \text { Arizona -- Greta J. Orris } \\
& \text { California (Southern) -- Floyd Gray } \\
& \text { New Mexico -- Norman J Page } \\
& \text { Texas -- Keith R. Long. }
\end{aligned}
$$

Arizona. MRDS data for Arizona initially consisted of records resulting from regional, district, and commodity studies done by the USGS in the 1970's and earlier. The data for Arizona's metallic mines and occurrences were reviewed and augmented by the Arizona Bureau of Geology and Mineral Technology in the early 1980's under a contract with the U.S. Geological Survey. CIMRI has added industrial mineral mines and occurrences, updated existing records for major metal deposits, and added new records for metallic mines that have been discovered or put into production since the middle 1980's. Within the limitations of the source publications, all of the new records and reviewed records have been located on 1:24,000 scale maps whenever possible. As of May 1993, only sand and gravel, flagstone-dimension stone, cinders, and pumice mines and occurrences had not been reviewed and added to this data set, but the data collection and review of these commodities had been initiated.

California (southern). MRDS data for southern California have been collected by a variety of USGS projects since the early 1970's, but the coverage is uneven in both a spatial and commodity sense. CIMRI's initial efforts to improve this data set have been to collect minerals data for Imperial County and for industrial minerals that were largely ignored by earlier work. With respect to the U.S. portion of the study area, this data set is probably the least comprehensive.

New Mexico. A contract with the New Mexico Bureau of Mines and Mineral Technology in the early 1980's established a comprehensive set of MRDS records for metallic mines and occurrences in New Mexico. Prior work by the USGS had resulted in a very small data set. As part of this study, CIMRI has updated and added information on metallic mines and occurrences where needed and compiled an industrial minerals data set for MRDS.

Texas. Prior to CIMRI's borderlands study, almost no data existed in MRDS for Texas outside of the Trans-Pecos area in West Texas. Records for West Texas have been updated and new records, nearly all of which are for industrial minerals, have been added for the remainder of the border region of Texas.

\section{Mexico}

Responsibility for upgrading and enlarging the mineral data set for the Mexico portion of the study was distributed by state amongst CIMRI staff as follows: 
Baja California Norte -- John-Mark G. Staude

Chihuahua -- John-Mark G. Staude

Coahuila -- John-Mark G. Staude

Nuevo Leon -- Keith R. Long

Sonora -- John-Mark G. Staude

Tamaulipas -- Keith R. Long

Greta J. Orris contributed records on industrial mineral mines and occurrences throughout the region.

Baja California Norte/Sonora. Data for these states were largely collected in the mid- to late-1980's (Leonard, 1989). Since the 1989 publication, new data for industrial minerals and metallic mines have been added to the Baja California Norte data set, substantially increasing the number of sites previously documented. The Sonora data set has also been enhanced by the addition of sites for both industrial minerals and metals. Data additions and changes made since the 1989 publication are reflected in the MRDS data sets for this area.

Chihuahua. Nearly all data in MRDS for Chihuahua were compiles from the literature by CIMRI. All occurrences within a radius of $2 \mathrm{~km}$ of one another are considered to be a single site. Locations of individual sites were determined using 1:50,000 topographic and geologic maps. Geology and other pertinent data were added to the records from Gonzalez-Reyna (1956) and over 100 other books and articles that are referenced in the individual MRDS records.

Coahuila. Data for Coahuila were also largeiy compiled by CIMRI. As in Chihuahua, most mineral occurrences within a radius of $2 \mathrm{~km}$ are considered to be a single site. Locations were determined using 1:50,000 scale topographic and geologic maps. Records for some industrial minerals represent a single deposit or mine and do not include other occurrences within a $2 \mathrm{~km}$ radius.

Nuevo Leon/Tamaulipas. The data sets for these states were compiled by CIMRI; few MRDS records existed for these states prior to this study. Most of the mineral deposits for these states are for industrial minerals. Although metals occur, there are few mines with a metal as the major commodity of interest.

\section{METALLIC MINERALS}

The distributions of MRDS records for the study area that list Ag, $\mathrm{Au}, \mathrm{Cu}, \mathrm{Pb}-\mathrm{Zn}$, or $\mathrm{Sn}$ listed as the major commodities are shown in figures 3 through 7 . The reader should note the following: there are no known major gold deposits in the data sets for Coahuila, Nuevo Leon, or Tamaulipas and there are no known major $\mathrm{Pb}-\mathrm{Zn}$ occurrences in Baja California Norte. Minor occurrences of these metals are present in these areas but are not shown in the figures. The lack of 


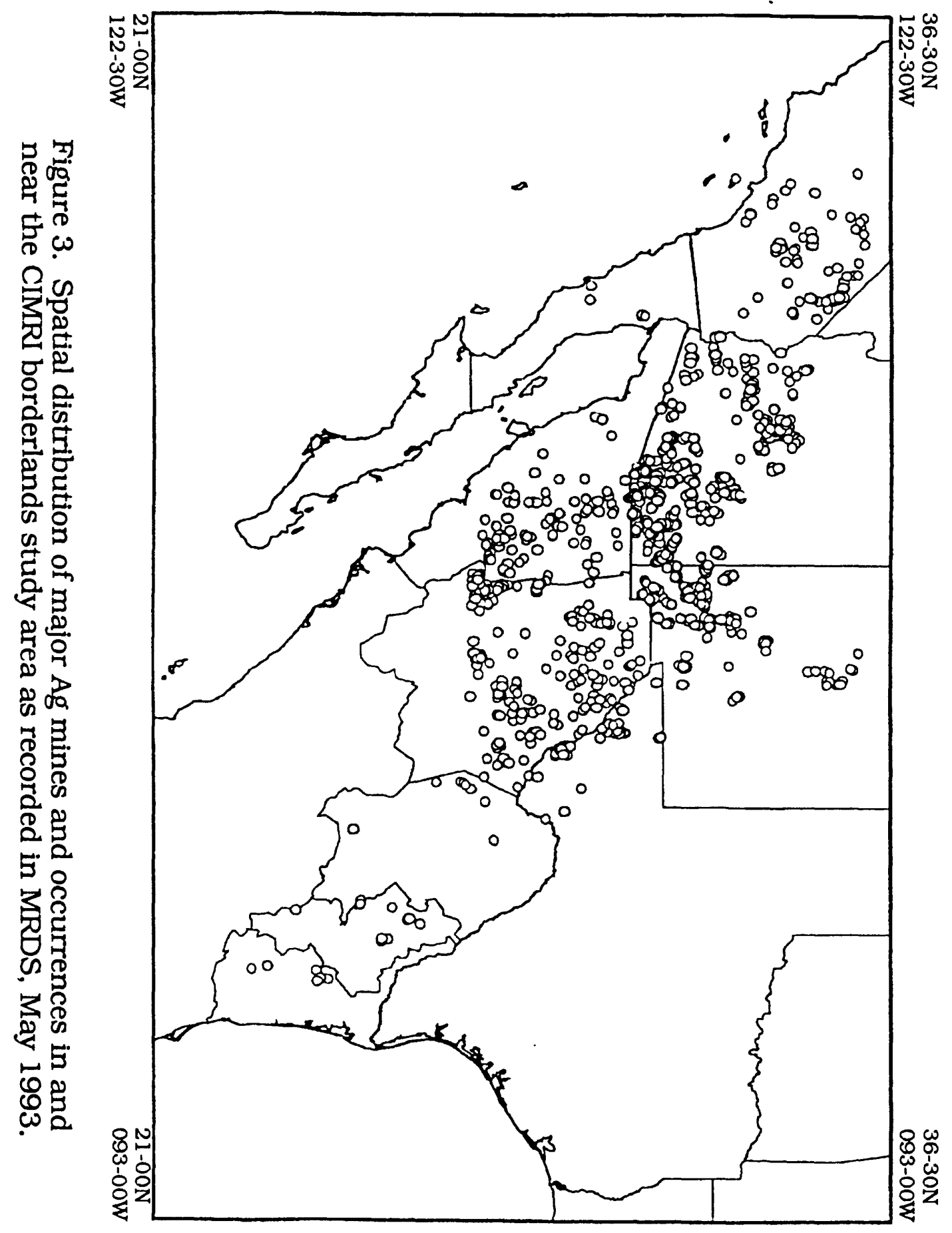




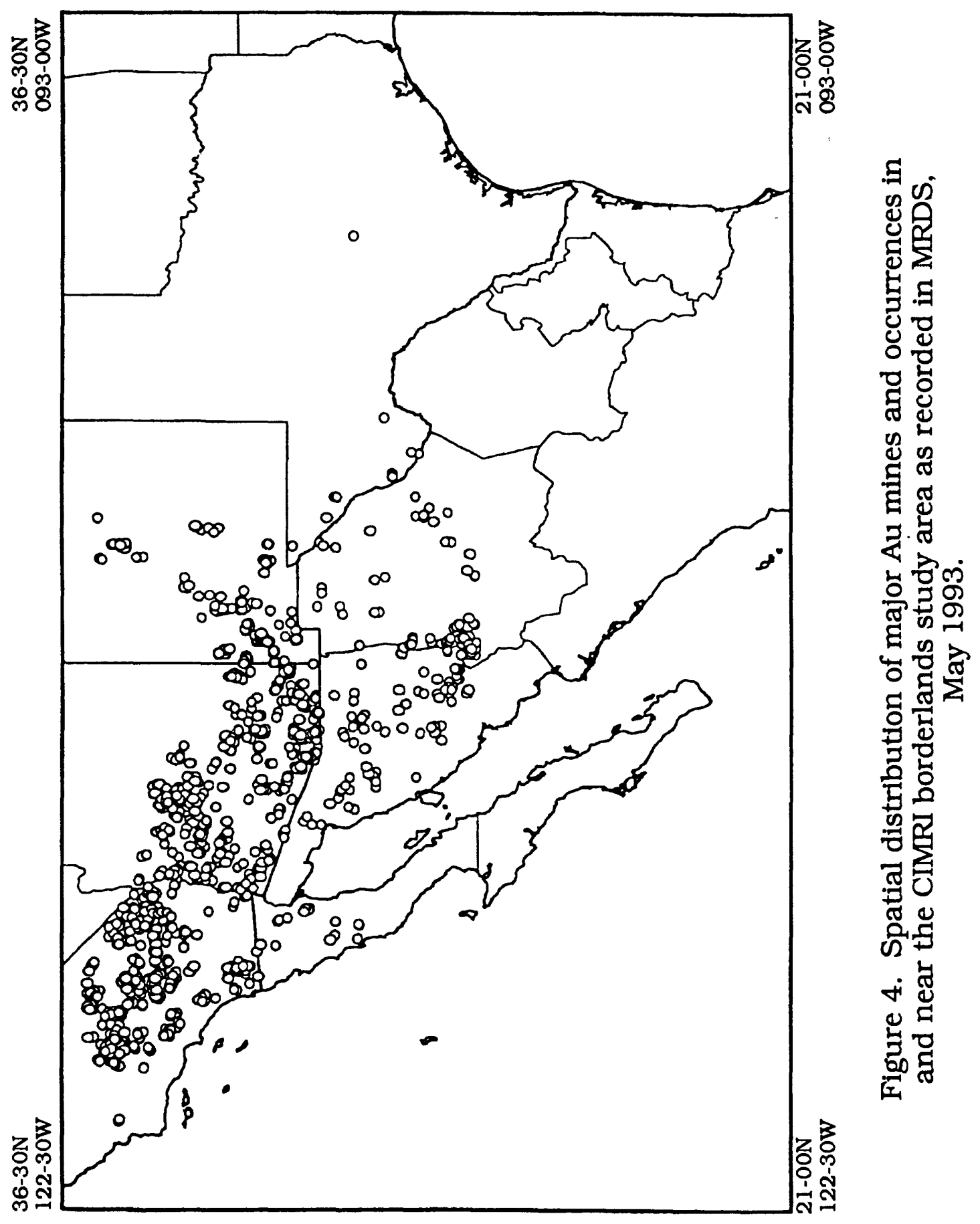




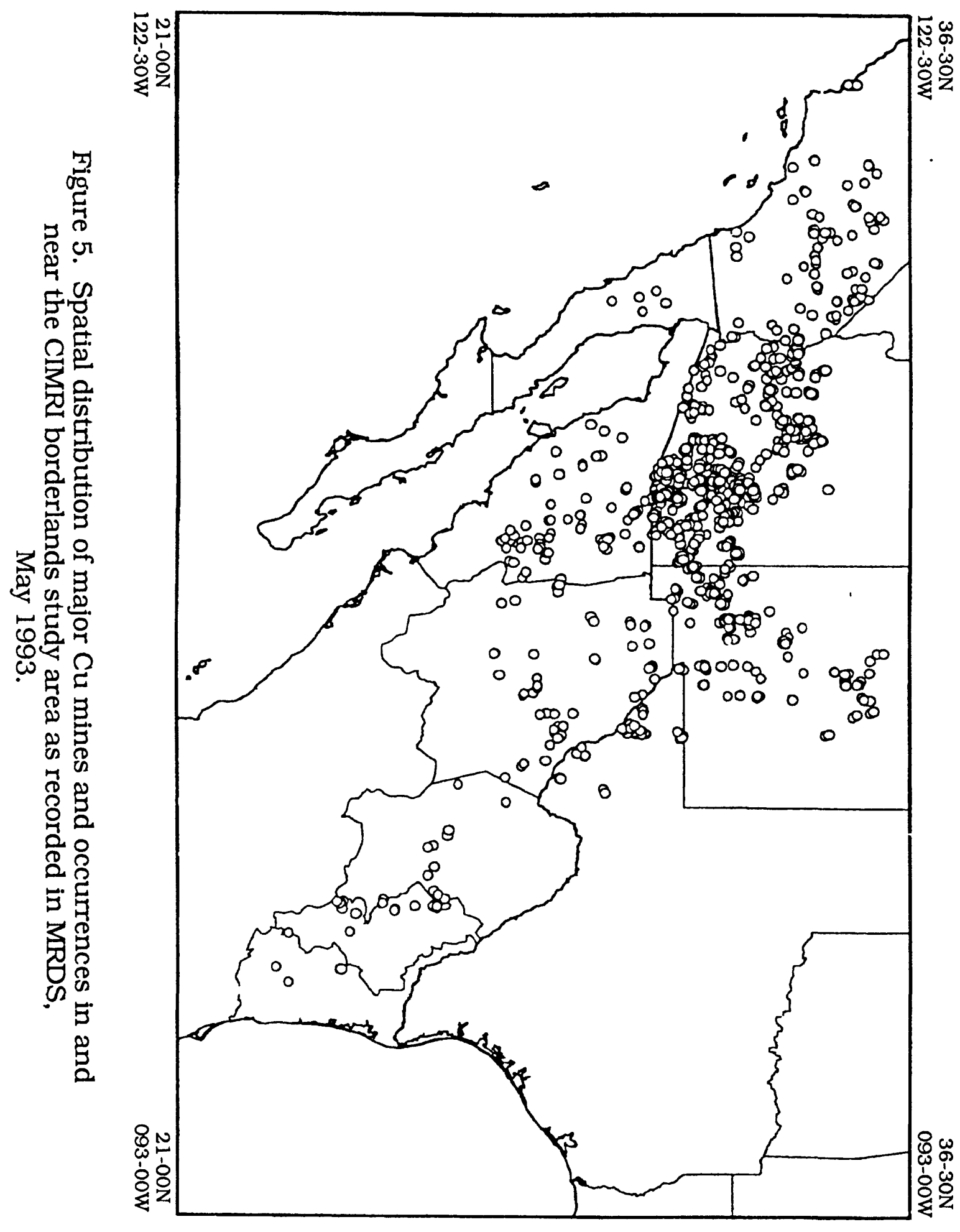




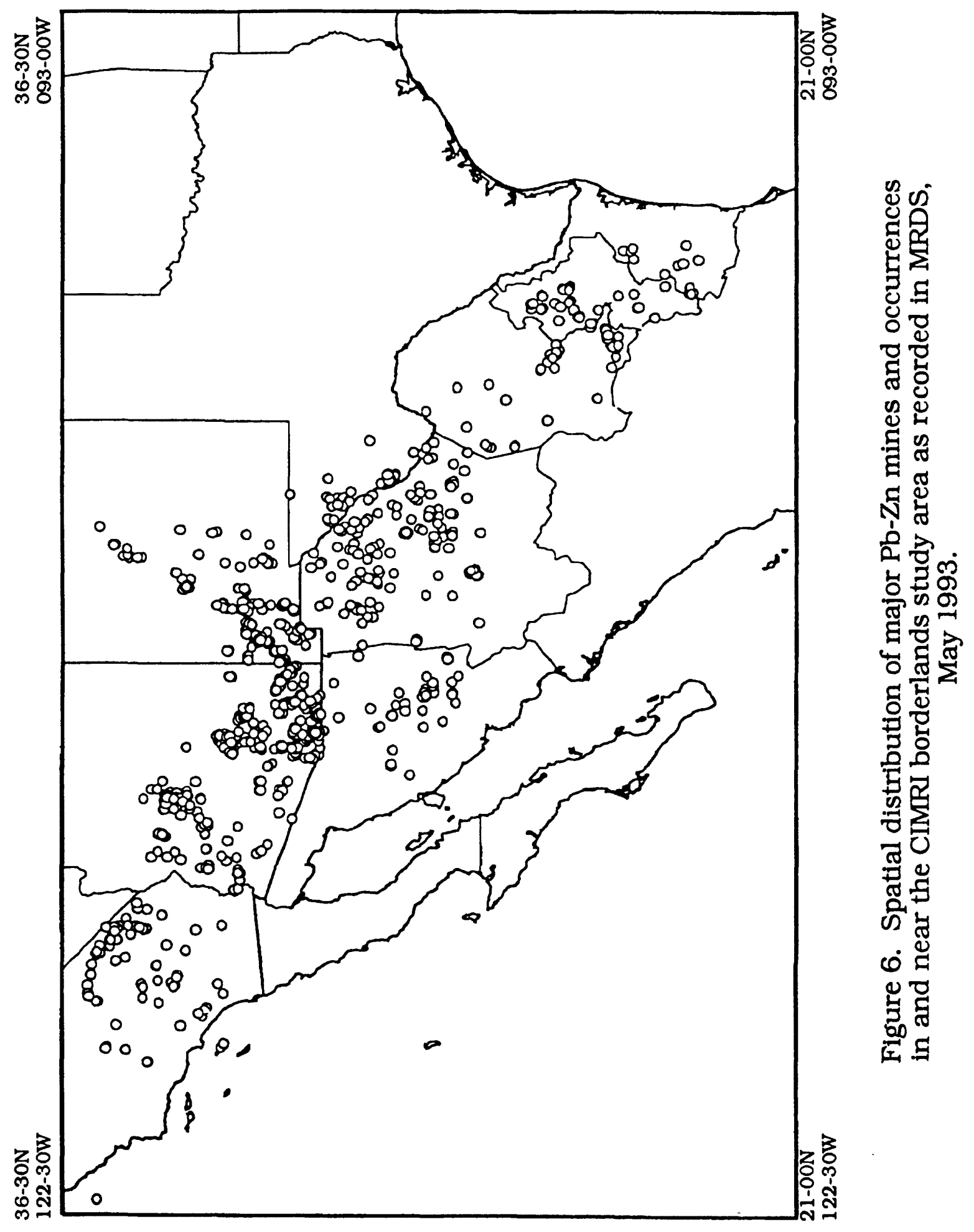




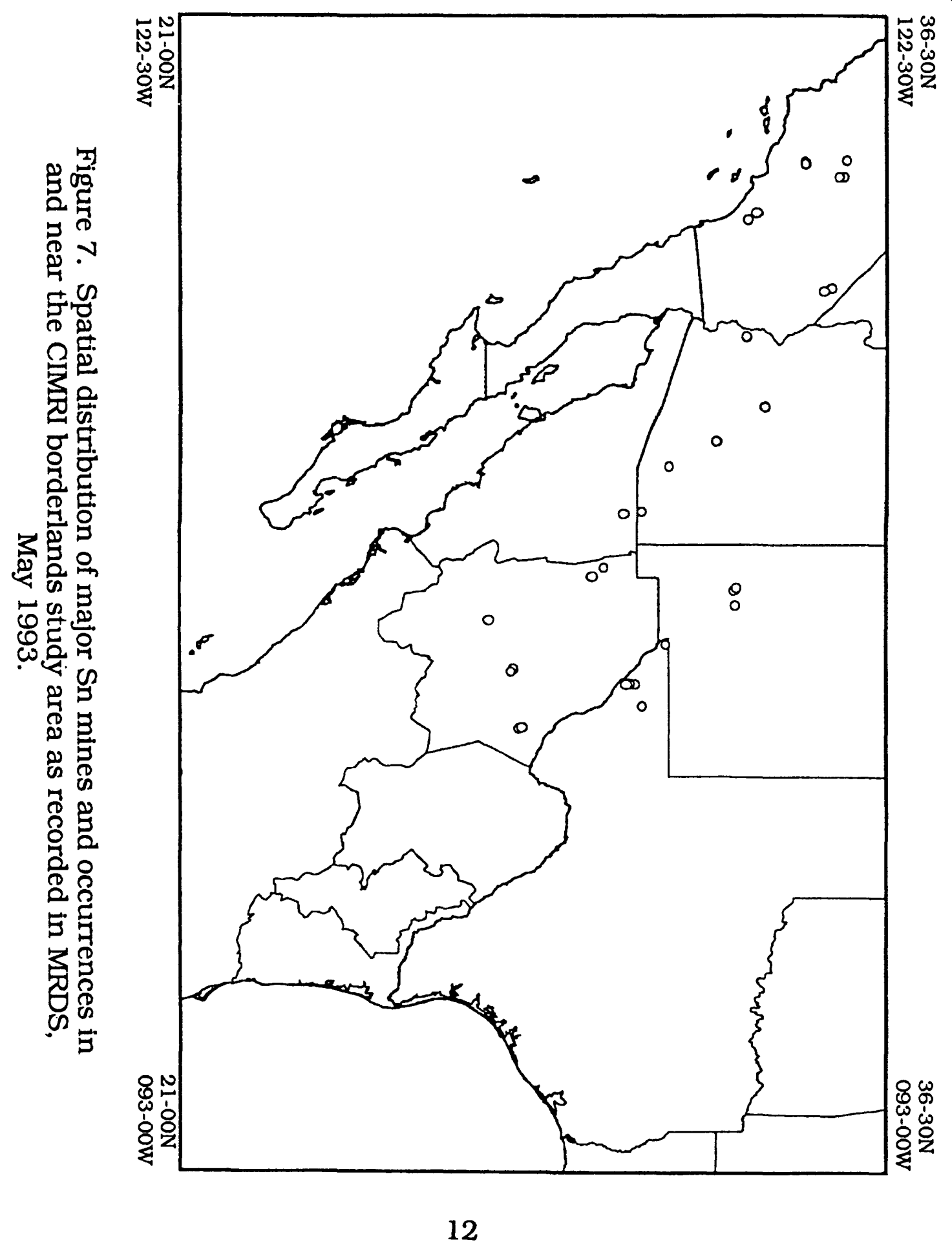


major metal deposits in Baja California Norte, Coahuila, Nuevo Leon, and Tamaulipas may represent a lack of exploration or may reflect underlying geologic controls.

\section{INDUSTRIAL MINERALS}

The distributions of industrial mineral deposits in MRDS are shown in figures 8 through 23. Commodities represented in the figures include barium-fluorine-strontium, boron, clay, diatomite, feldspar, gypsum, halite, limestone, perlite, phosphate, rare earth elements (REE), sand and gravel, dimension and crushed stone, sulfur, and zeolites. With respect to the study area, most of the new records added to MRDS by CIMRI have been for industrial mineral deposits. California has the least complete data set within the study area. Records of sand and gravel and dimension stone have not yet been completed for Arizona, because the number of mines and occurrences for these commodities is very large. It should be noted that the industrial minerals data set for much of the study area is not as exhaustive as that for metals. The collection of industrial minerals data is too preliminary to draw significant conclusions about their distribution.

\section{REFERENCES}

Gonzalez-Reyna, Jenaro, 1956, Memoria geologico -- minera del Estado de Chihuahua (minerales metalicos): XX Congreso Geologico Internacional, $280 \mathrm{p}$.

Leonard, K.R., 1989, Preliminary deposit-type map of northwestern Mexico: U.S. Geological Survey Open-File Report 89-158, 352 p., scale $1: 1,000,000$.

Silver, L.R., and Anderson, T.H., 1978, Mesozoic magmatism and tectonism in northern Sonora and their implications for mineral resources, in Resumenes 1o Simposio Sobre la Geologia y Potencial Minera del Estado de Sonora: Instituto de Geologia, Universidad Nacional Autónoma de México, p. 117-118. Mayo de 1978 


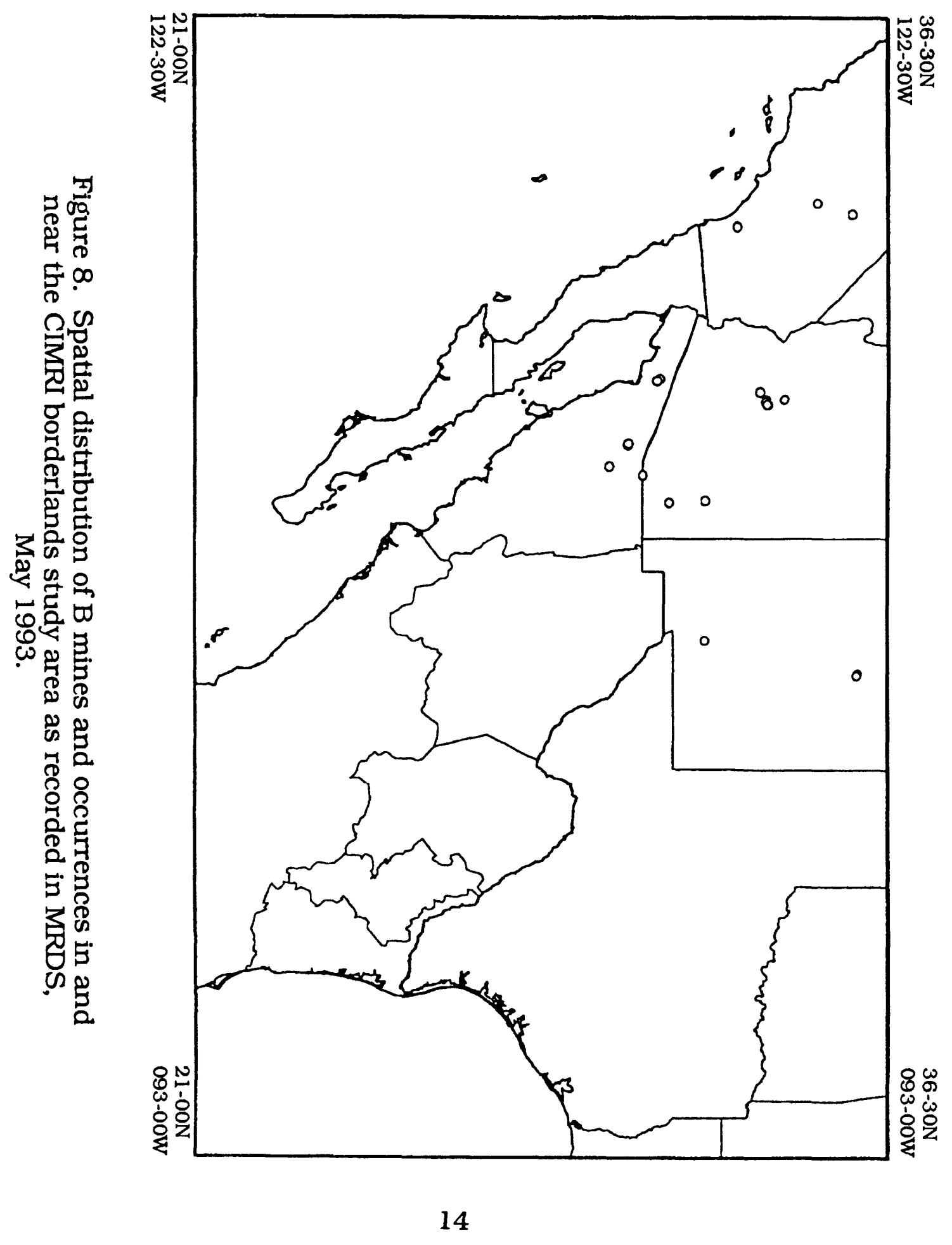




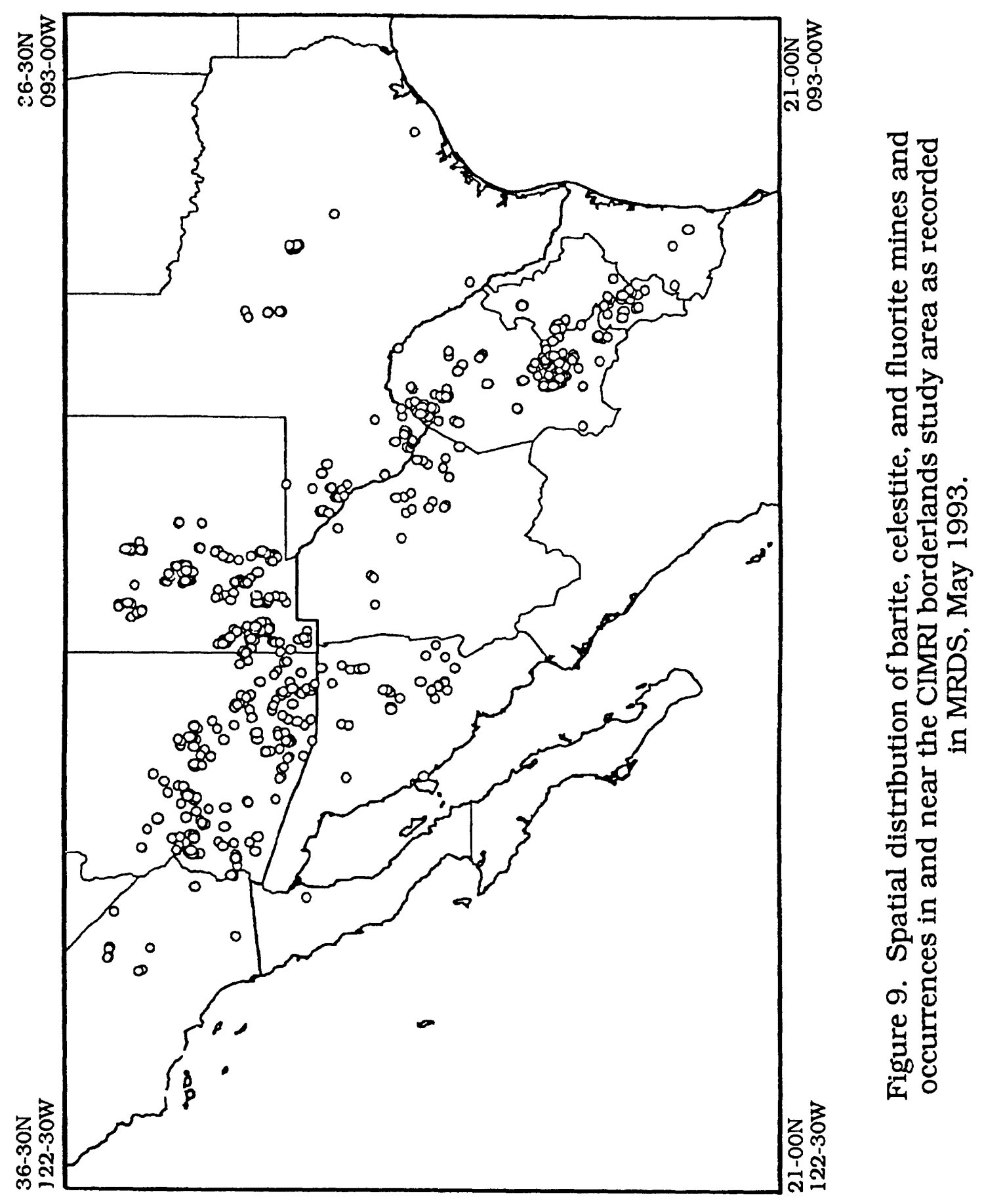




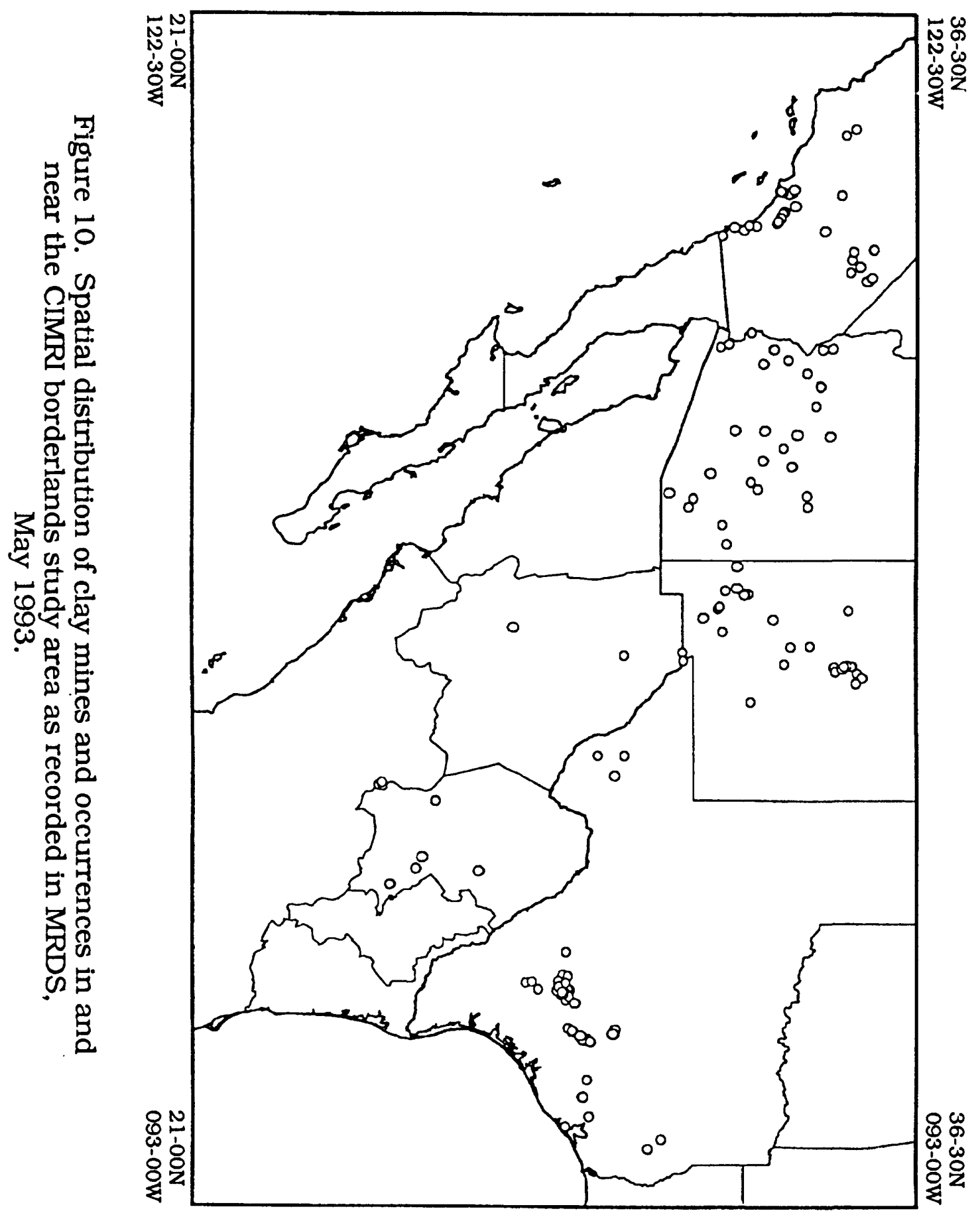




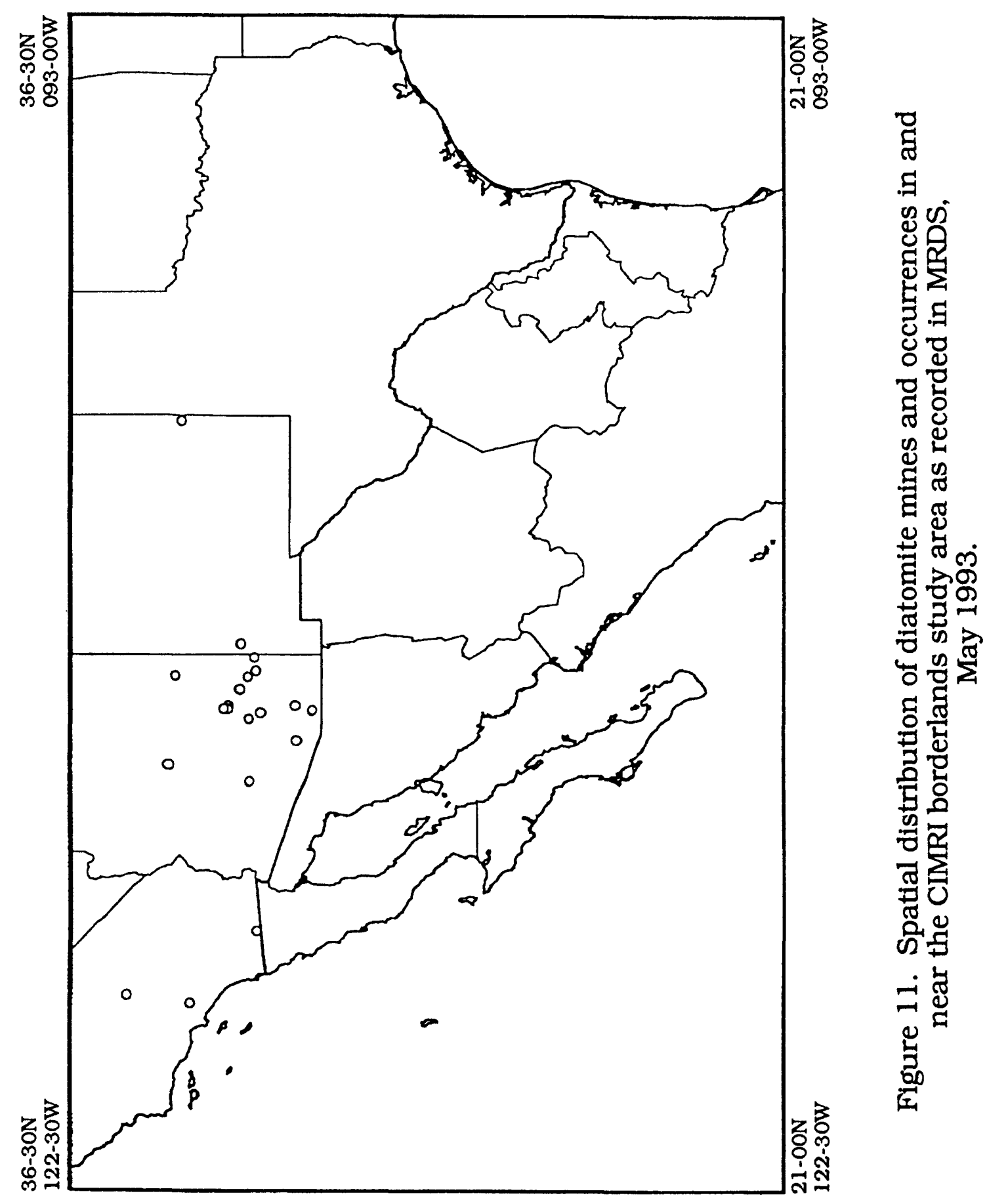




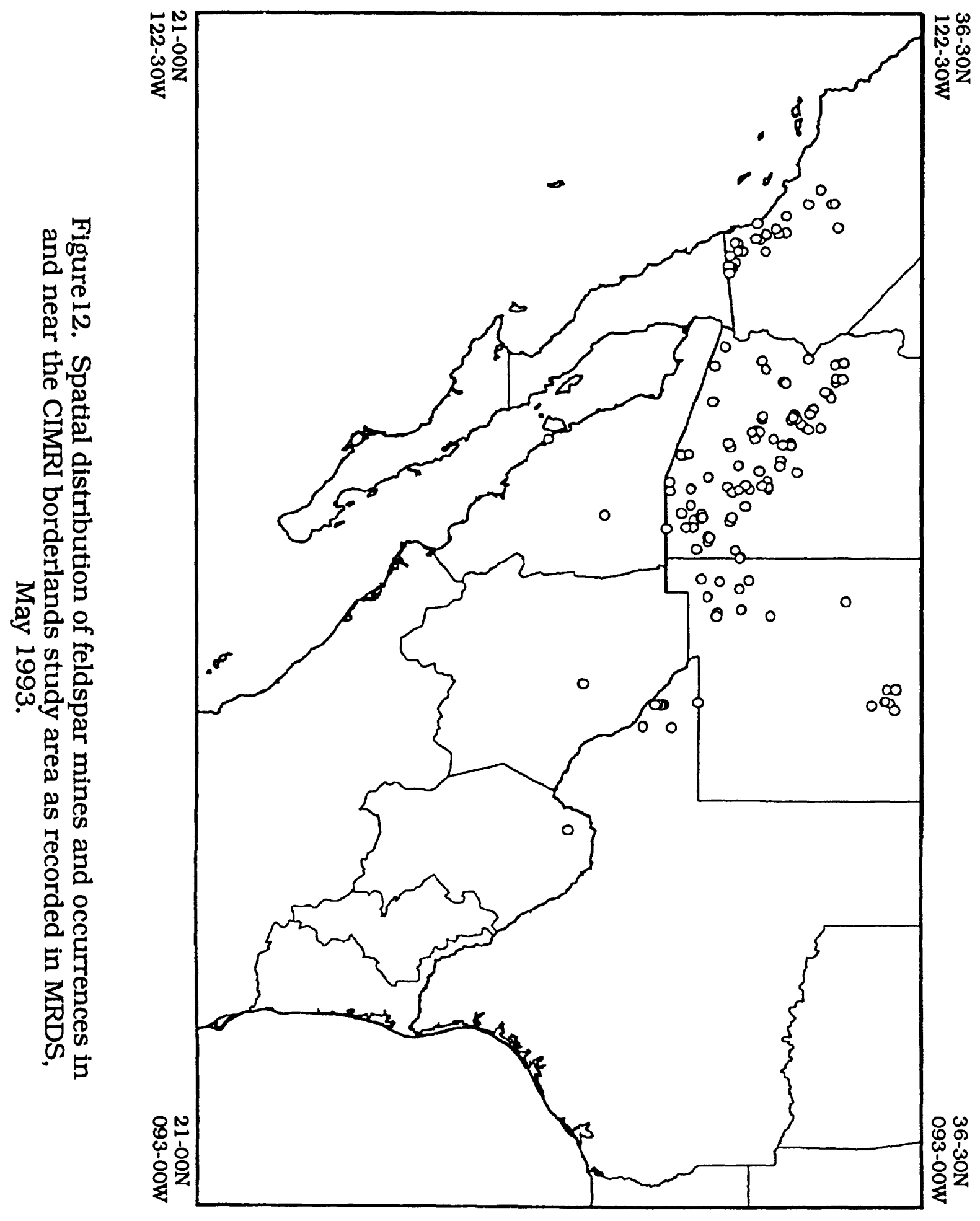




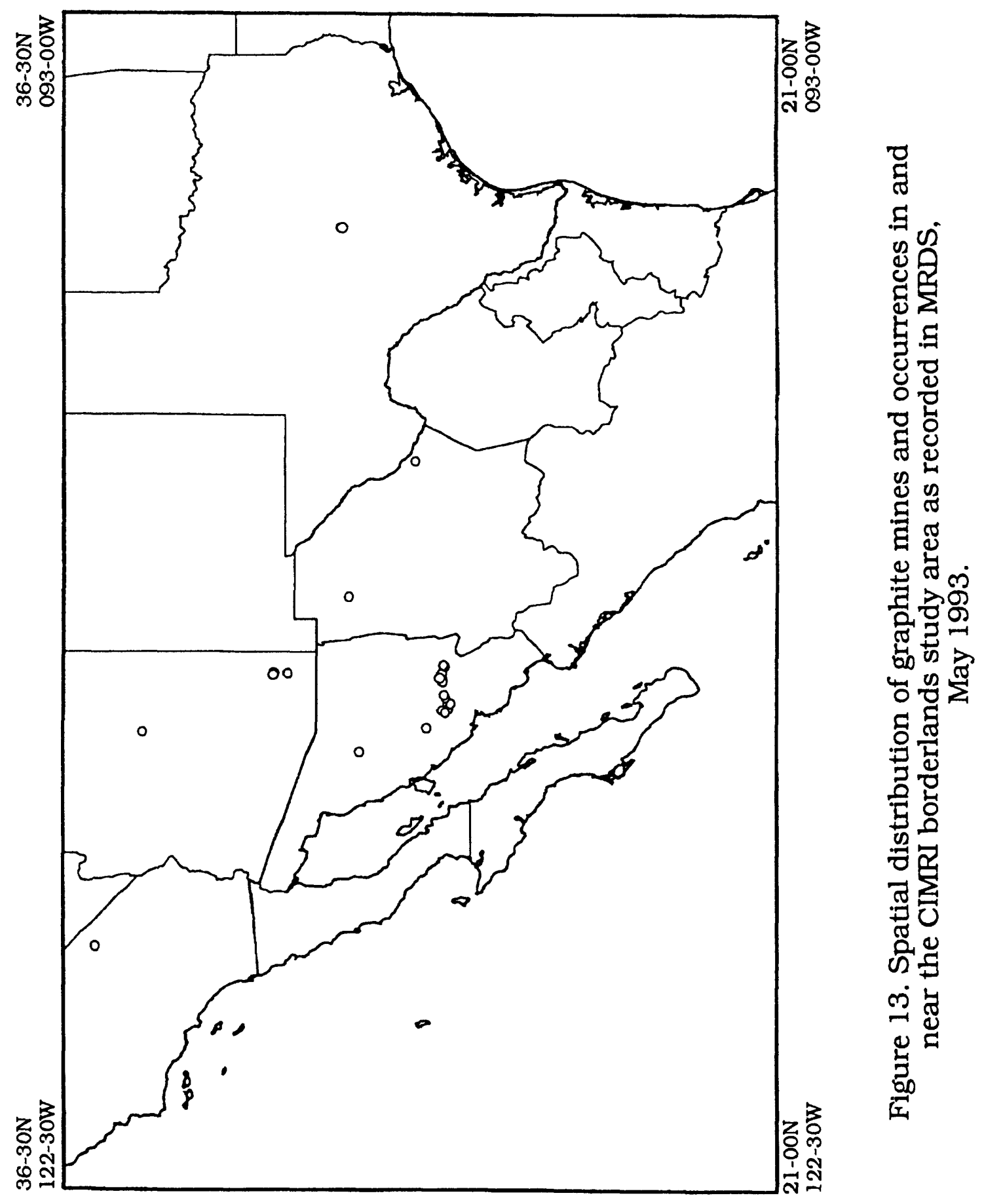




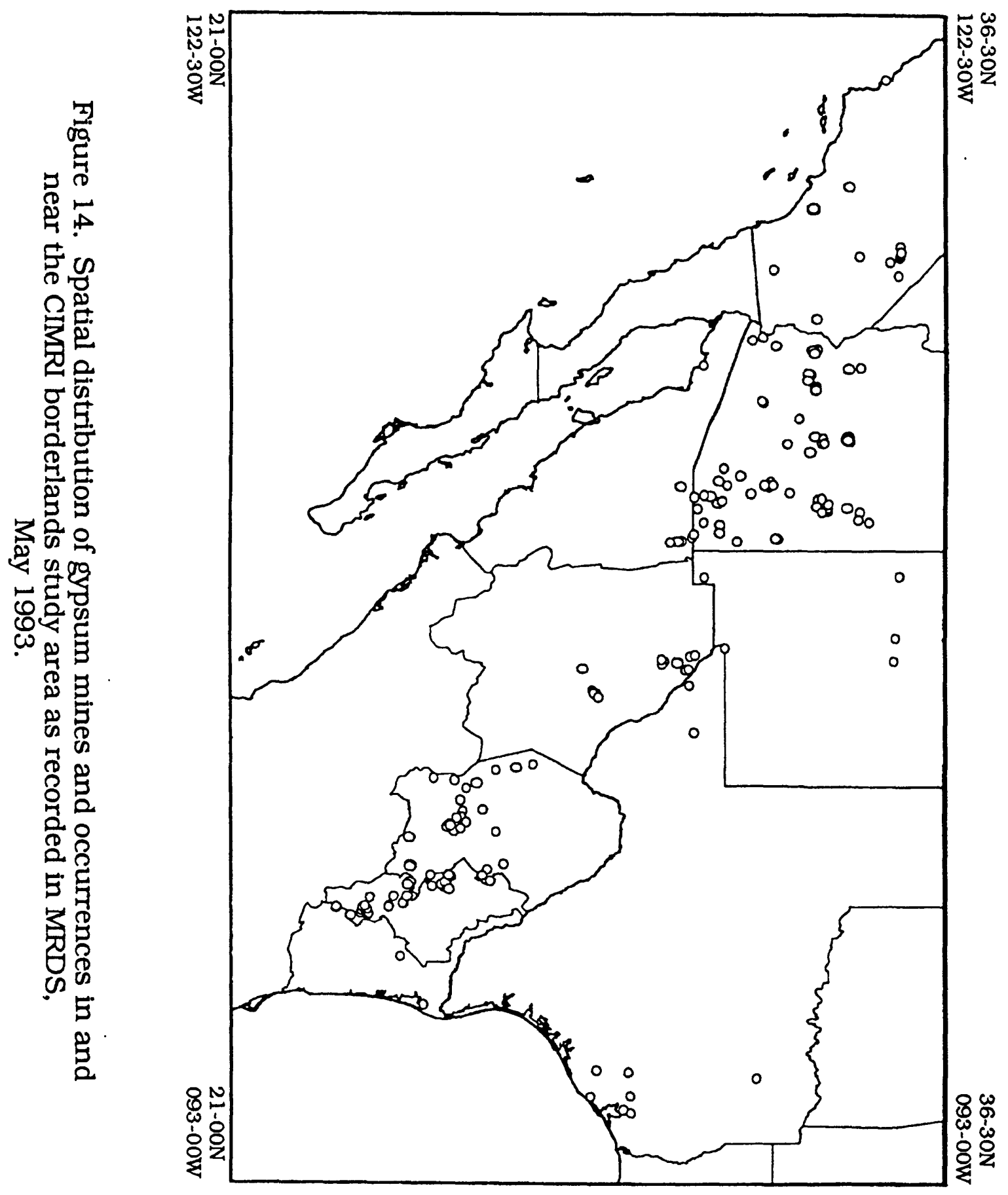




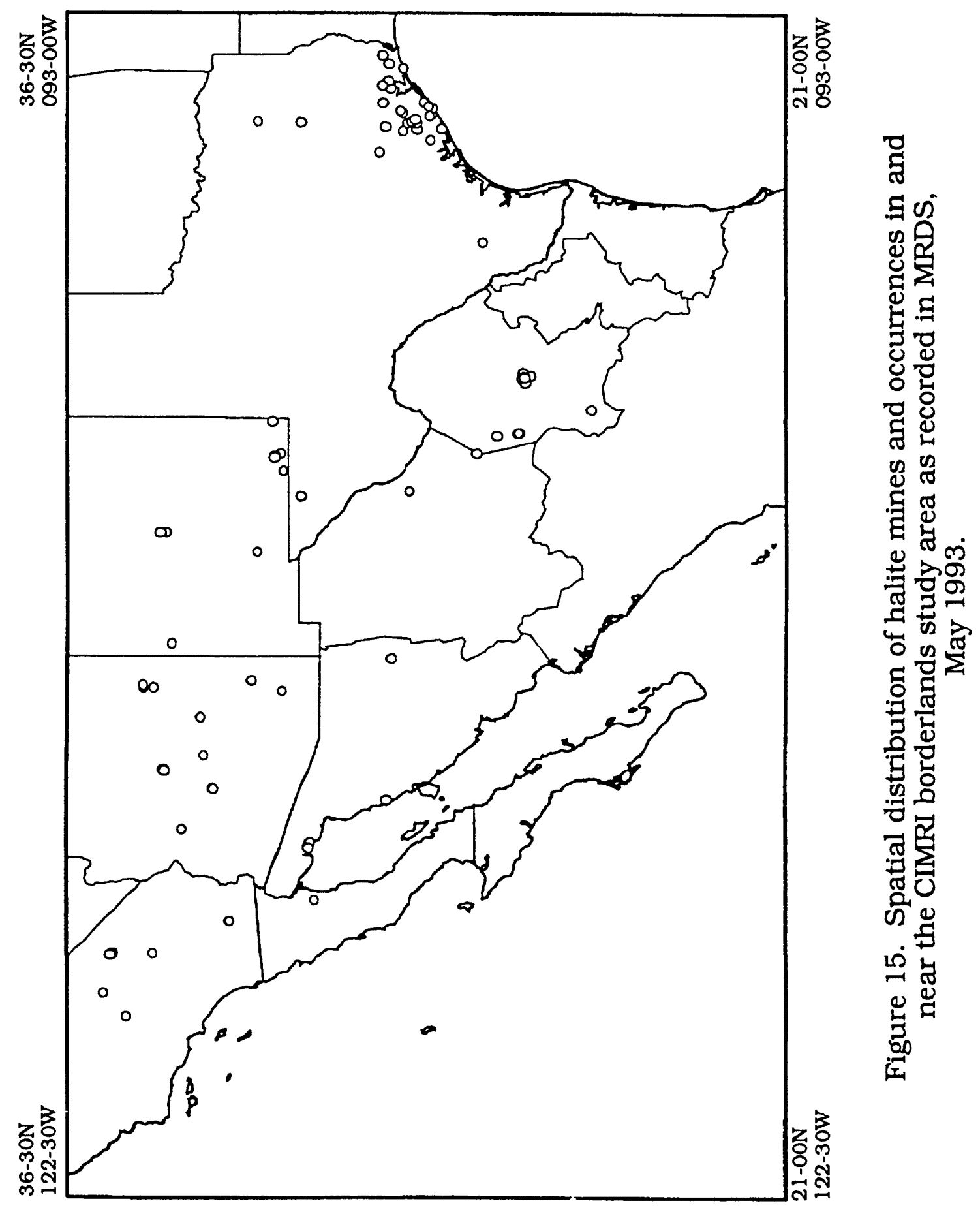




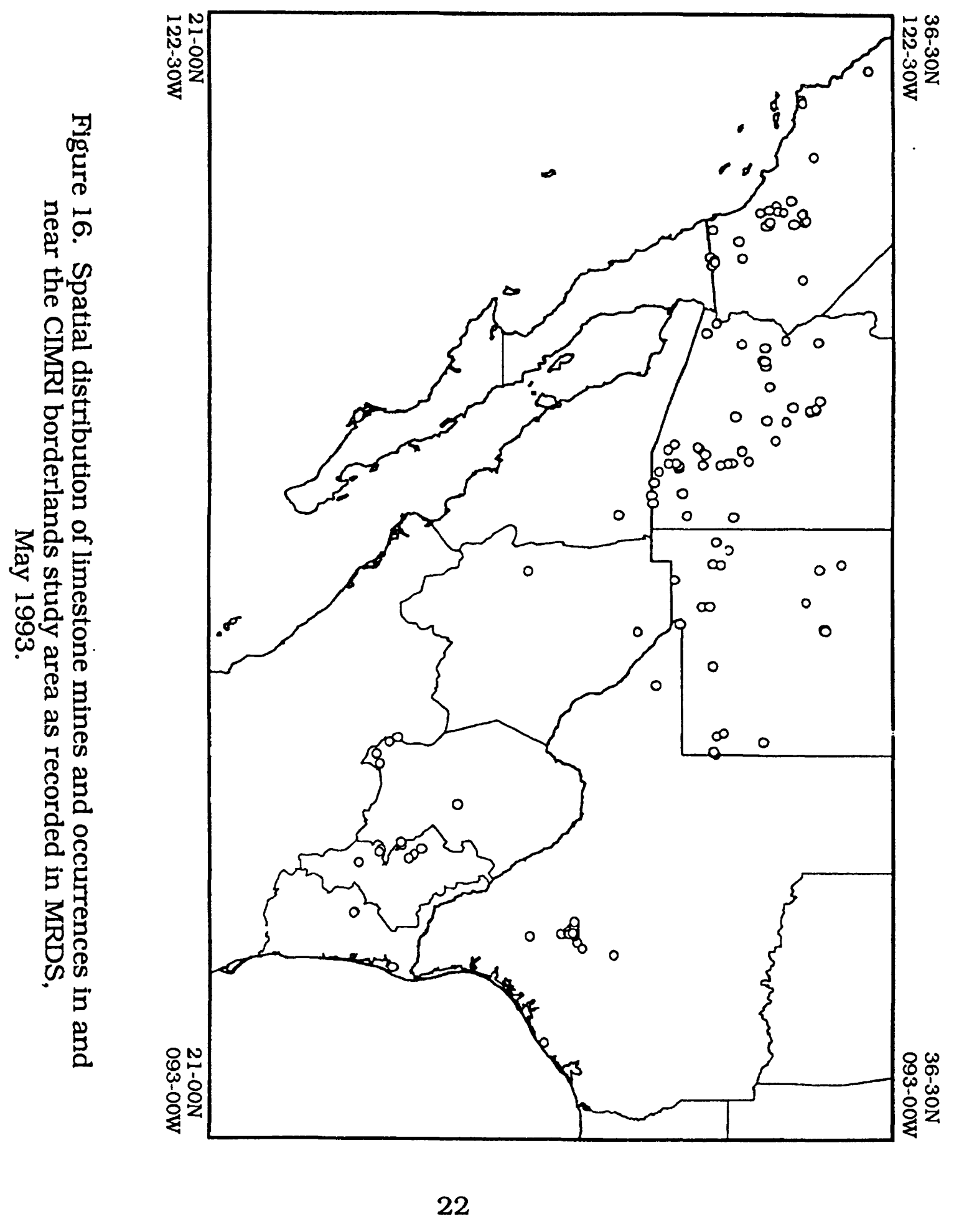




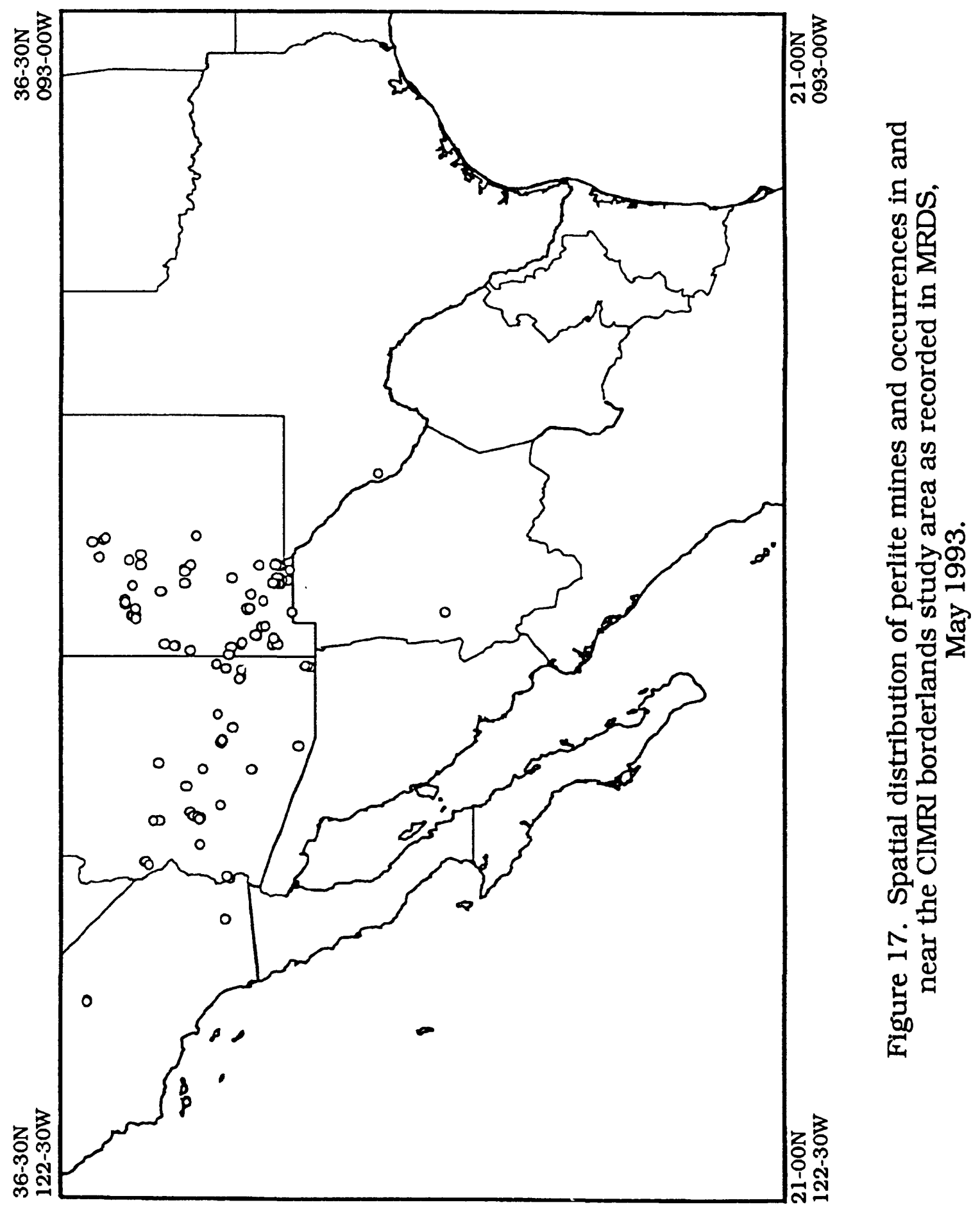




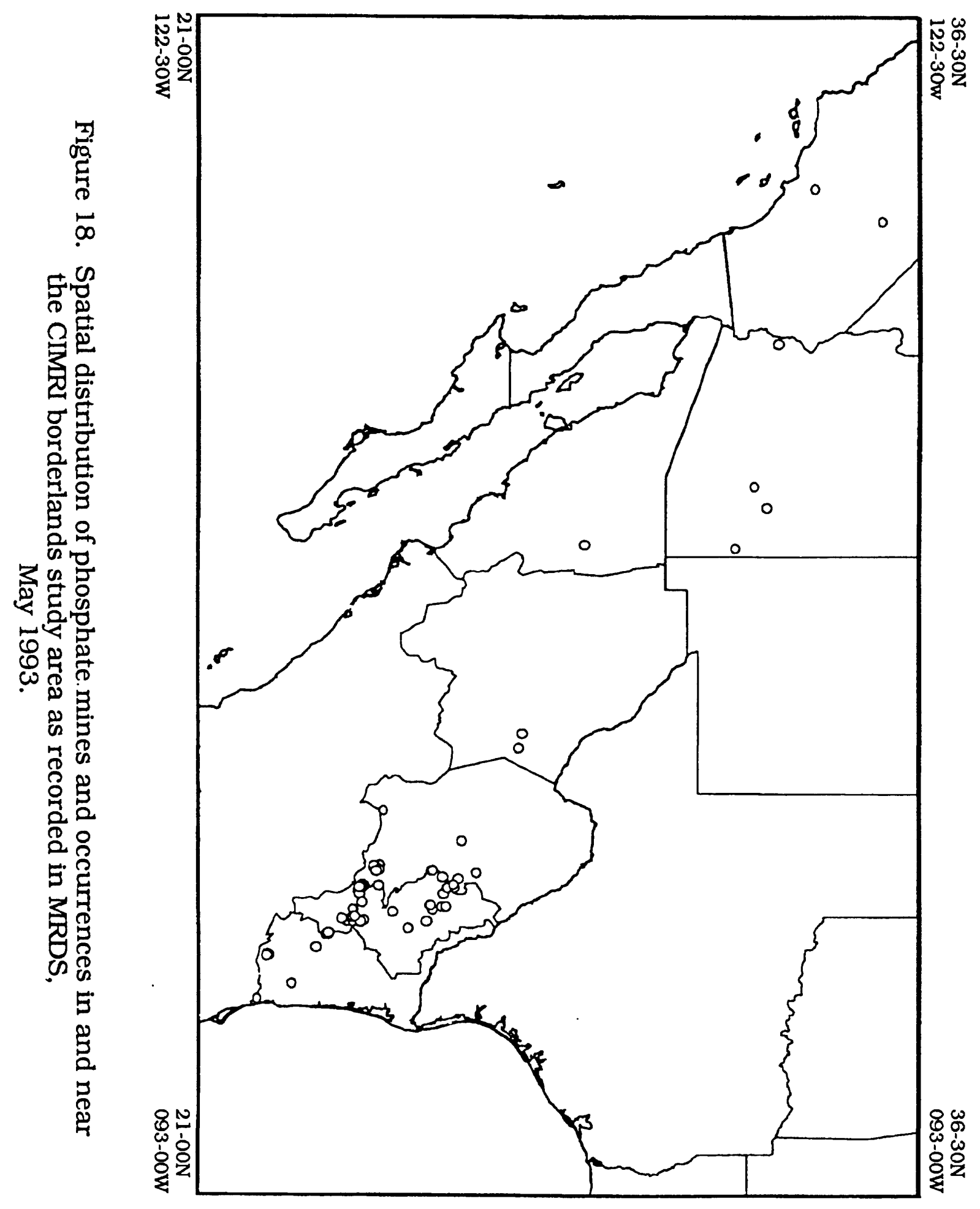




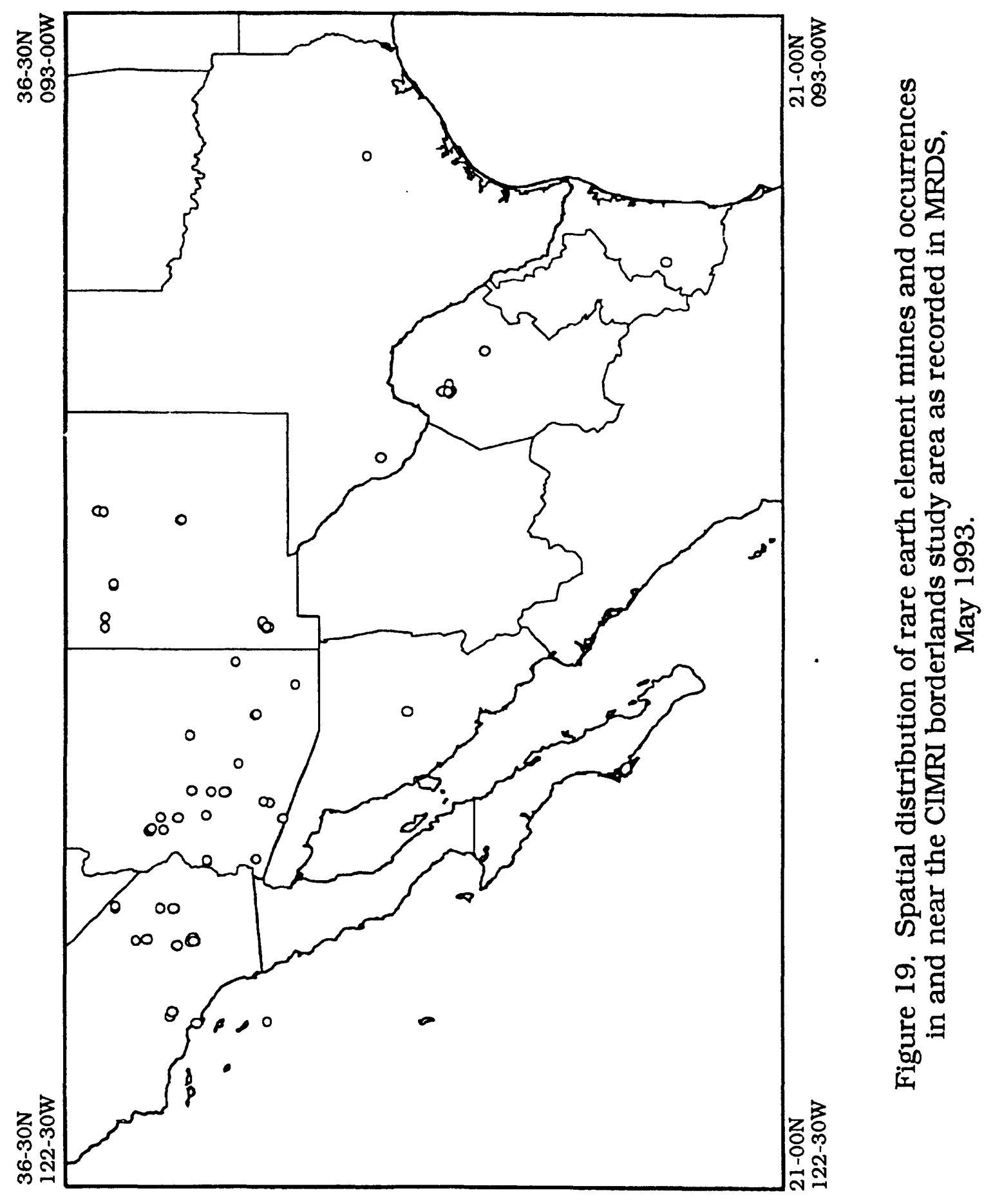




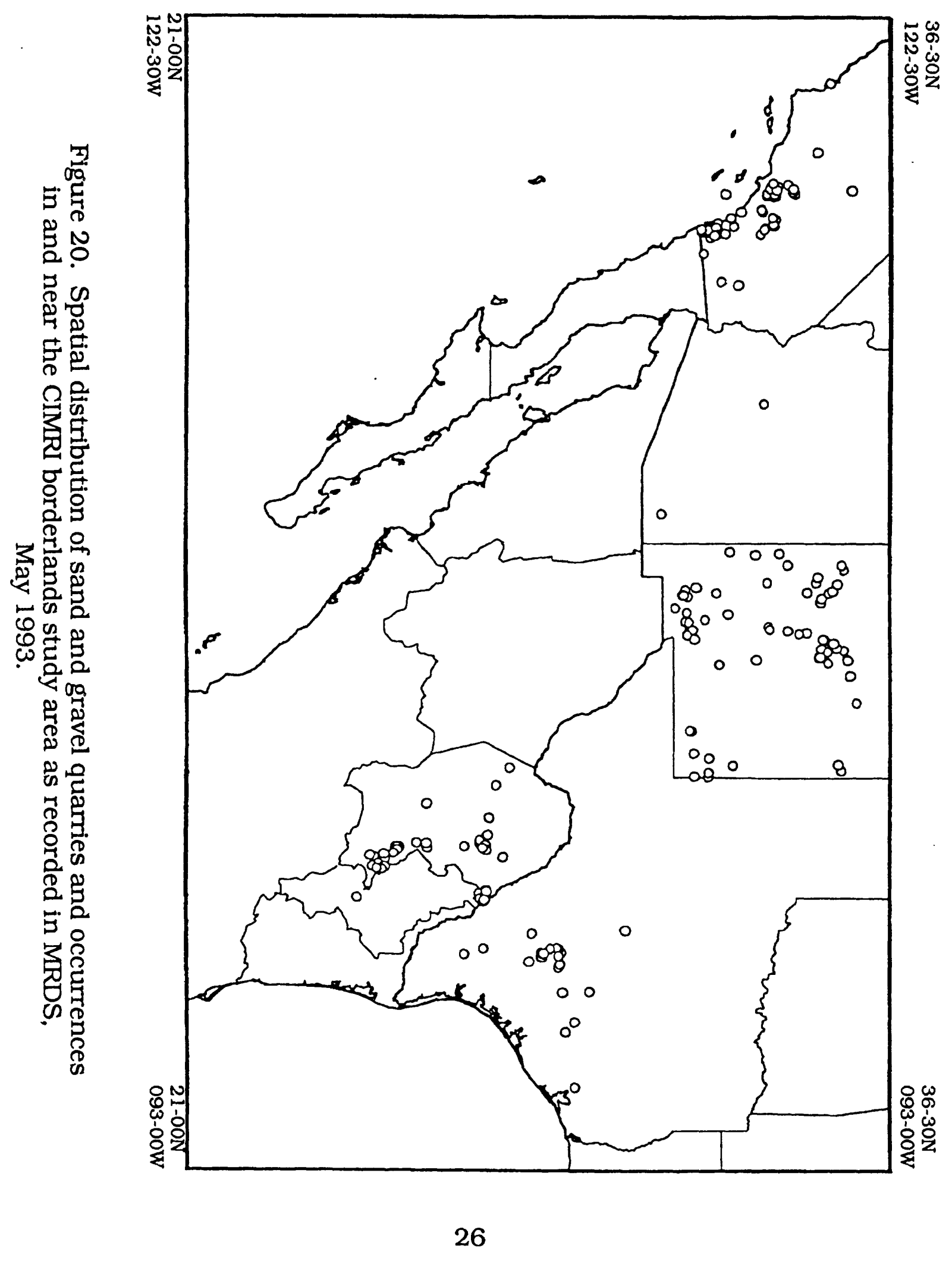




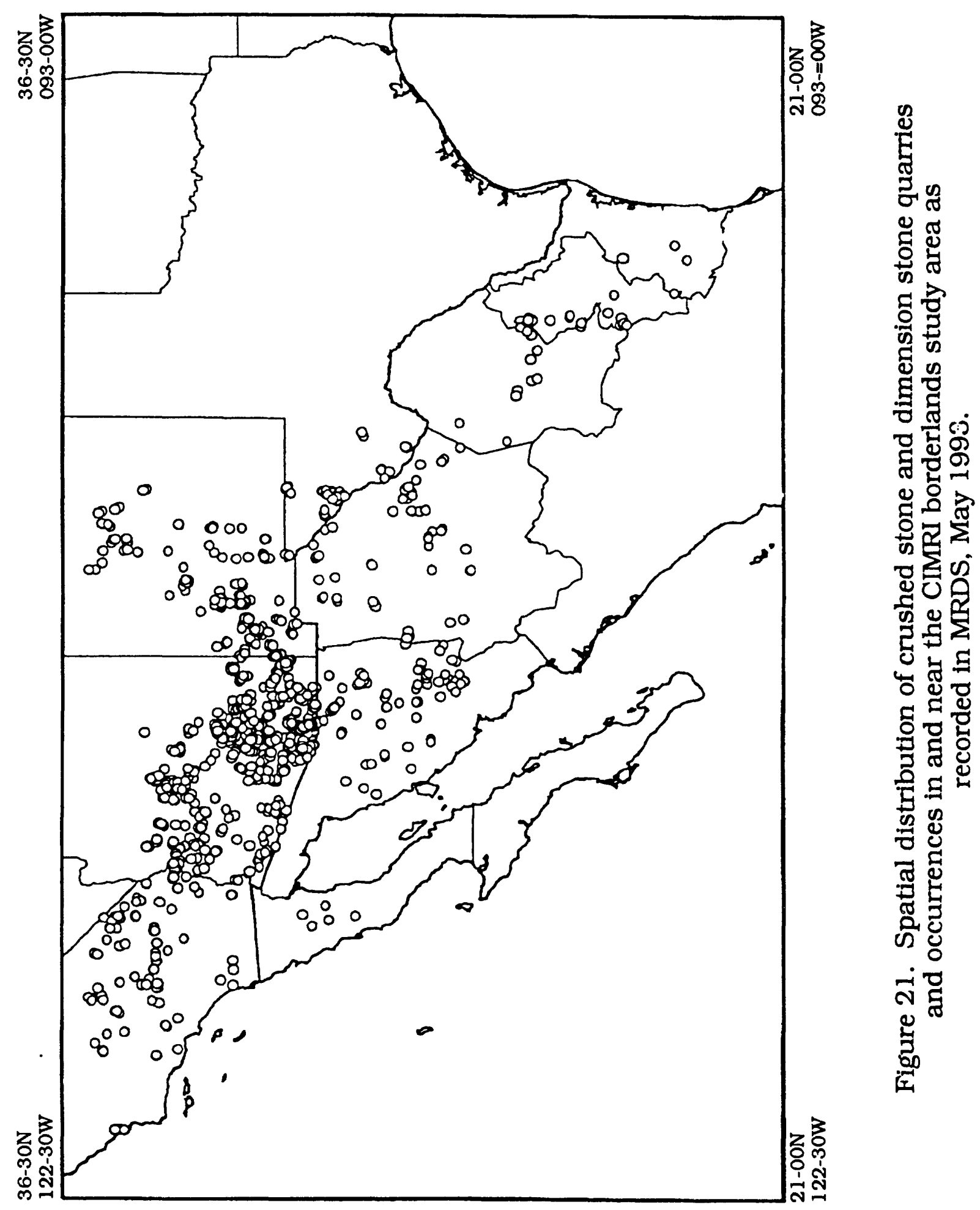




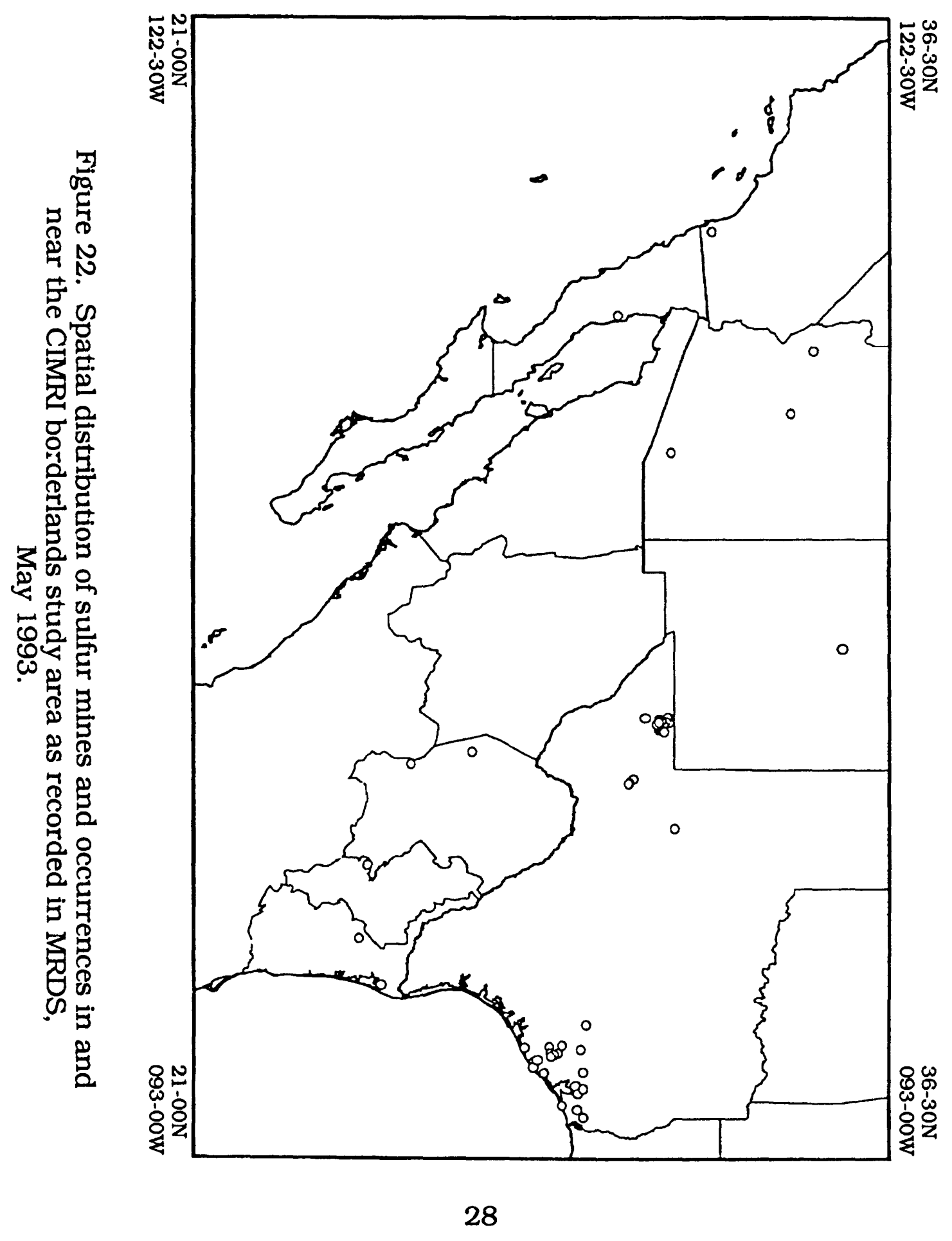




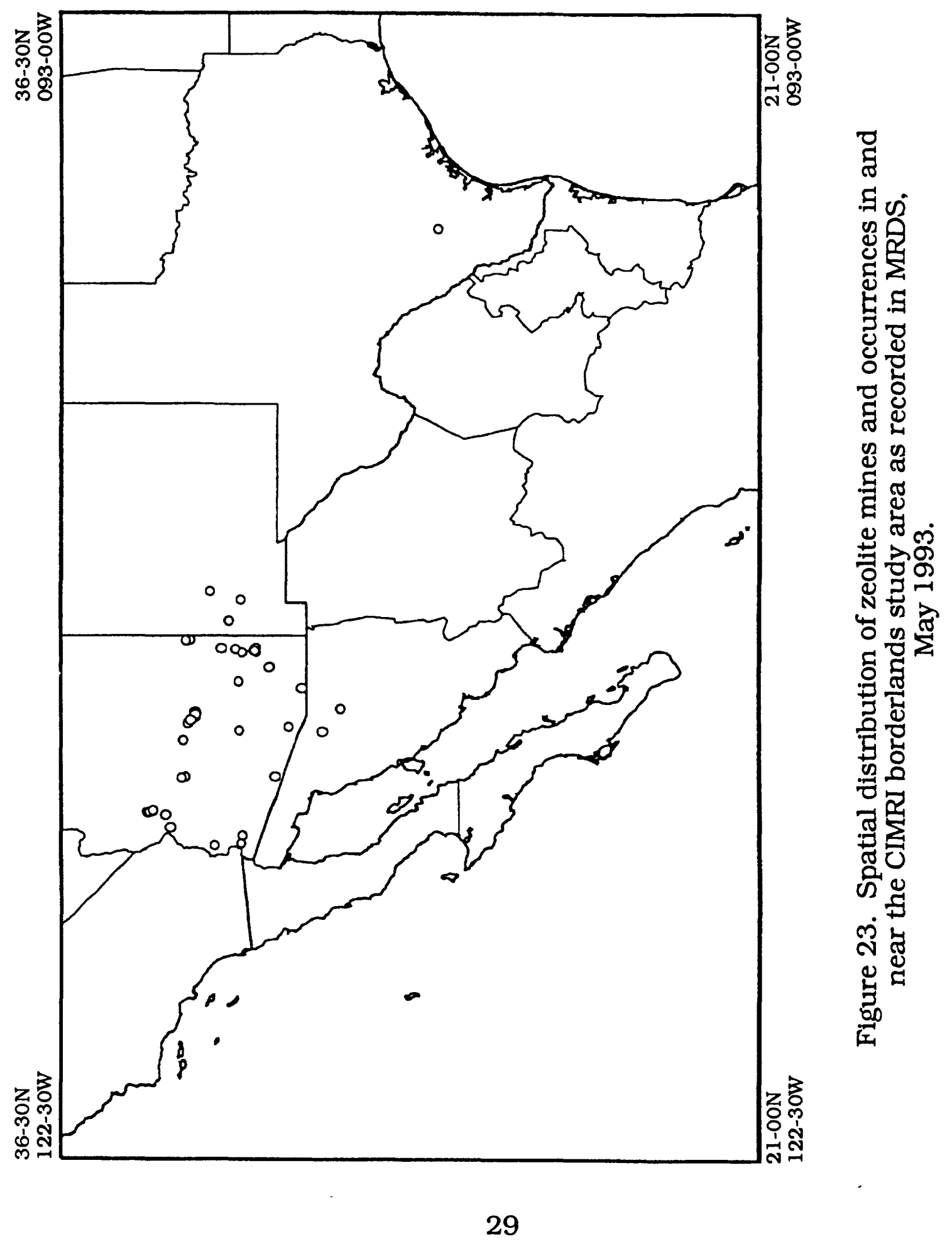

